\title{
MOTIVES STILL DON’T MATTER: REPLY TO PYNES
}

\section{by Andrés Ruiz and Jeffrey Koperski}

\begin{abstract}
This paper continues a dialogue that began with an article by Jeffrey Koperski entitled "Two Bad Ways to Attack Intelligent Design and Two Good Ones," published in the June 2008 issue of Zygon: Journal of Religion and Science. In a response article, Christopher Pynes argues that ad hominem arguments are sometimes legitimate, especially when critiquing Intelligent Design (2012). We show that Pynes's examples only apply to matters of testimony, not the kinds of arguments found in the best defenses of ID.
\end{abstract}

Keywords: $\quad$ ad hominem; Darwinism; evolution; intelligent design

Christopher Pynes (2012) contends that, contra Koperski (2008), ad hominem arguments against Intelligent Design are not fallacious. He holds that such arguments are perfectly legitimate ways to criticize ID. We show why Pynes's counterexamples miss the mark. While fallacies can be rhetorically effective, they are a distraction best avoided by scholars. Motive mongering and ad hominem attacks should be set aside when assessing ID.

First, a few quibbles. Pynes wrongly states that "all ID theorists are theists" (291). In fact, Discovery Institute Fellow David Berlinski is an agnostic. Philosopher and atheist Bradley Monton is the author of Seeking God in Science: An Atheist Defends Intelligent Design. There are others, but those two are enough to refute Pynes's blanket claim.

The second quibble: Pynes says, "Just like methodological naturalism is a tenet of science, supernaturalism is a necessary component of ID" (296). This is false. ID does not require supernaturalism; it merely recognizes the need for agency as a legitimate explanatory resource. The agent need not be a supernatural being (Dembski 2007, 223). Proponents have repeatedly said that an extraterrestrial intelligence is perfectly compatible with the evidence for ID (Behe 2001, 165). One of the reasons so many Young Earth Creationists initially rejected ID was because it allowed too many possible designers, not all of which are supernatural. These are minor quibbles, but allowing them to accumulate eventually creates a strawman. Regardless of how one feels about ID, we should deal with what its proponents actually say.

Andrés Ruiz is a Teaching Associate at Ohio University, 205C West Washington, Athens, OH 45701, USA; e-mail: ar318307@ohio.edu. Jeffrey Koperski is Professor of Philosophy, Saginaw Valley State University, 7400 Bay Road, University Center, MI 48710, USA; e-mail:koperski@svsu.edu. 
Pynes's main point is that Koperski fails to distinguish ad hominem fallacies from legitimate ad hominem arguments. In the latter case, a person's circumstances matter when it comes to giving credence to his or her claims. One should be skeptical of the traveling salesman. His need to convince you in order to make a sale should lower your trust in his claims about the product. Likewise, one should be skeptical of the jailhouse snitch who will be released for telling the prosecutors what they want to hear. In both cases, the source of information has a clear conflict of interest. Keeping that point in mind, Pynes argues, is not a fallacy but rather a rational response in light of the source's bias.

We completely agree. There are circumstances in which a person's testimony is untrustworthy; the salesman and paid informant are good examples of this. The problem is that these cases are not analogous to ID.

Pynes believes that ID critics justifiably point to the apologetic bias of ID supporters, who march under the biblical mandate of the Great Commission. Given this religious motivation, "it is legitimate to be concerned in these cases" (296). And that is fine. One can be concerned about all sorts of things. The problem here is that concern about the religious motivations of ID theorists is completely irrelevant in assessing the arguments and evidence on the table. Pynes writes, "The issue of attacking or evaluating ID proponents in a manner that questions their credibility is justified when the truth of what ID theorists are asserting could be influenced by their beliefs and motives" (297, emphasis added). Are ID advocates merely asserting that an intelligence has been involved in the evolutionary process? They are not, and that is a key difference. Salespeople and jailhouse snitches have a conflict of interest, and therefore their testimony ought to be doubted. They are the only sources of information we have about the events and factual claims they have made. We only have access to those facts secondhand, through the testimony of those biased individuals. Given their motivations for either a sales commission or a lighter jail sentence, we have good reason to suspect that what they are telling us is not the whole truth.

Here, then, is the disanalogy: ID proponents are not offering firsthand testimony. They are not reporting events they have seen or presenting information that only they are privy to. It is not as if Michael Behe claimed to have seen the hand of God in his lab and we are supposed to take his word for it as evidence of Intelligent Design. No, ID proponents draw their evidence from published, peer-reviewed research on the bacterial flagellum, respiratory cilia, blood clotting cascade, and so on, and then provide arguments that naturalistic evolution lacks the mechanisms to produce such complex machinery. If one wishes to rebut these arguments, one can question either the published evidence or the logic of the inferences. What one cannot do is dismiss those arguments because of who is making them. A "refutation" that focuses on the motives of the individuals offering 
the argument is a textbook example of the ad hominem fallacy. This, we contend, is what critics do when attacking the religious motivations of ID proponents.

That such attacks are fallacies is clear in the best example mentioned in Koperski (2008), one that Pynes fails to mention. Consider ID critic Barbara Forrest and her motivations.

She is on the board of directors for the New Orleans Secular Humanist Association, a group that actively tries to prove that religious beliefs are based on ignorance and superstition. They strategically promote Secular Humanism; they hold conferences; they have their own newsletters and publications; they take donations. (436)

If Pynes is to be consistent, one could refute Forrest's arguments simply by pointing to her antireligious motives. If one were to do so, however, Forrest would rightly complain that one must address the evidence and arguments she has presented, not merely smear her as a clenched-jawed atheist. Once premises with publicly available information are presented and an argument made, logic demands that one address that argument rather than attack the source. This is true for any argument form: deductive, inductive, or abductive.

Finally, consider the ramifications of adopting Pynes's view. Say that an ID scientist admitted this in print: "When I wrote my book, I had an eye on principles that might help people considering belief in God. Nothing would make me happier than to see it used for that purpose." In Pynes's view, this sort of "Great Commission" end is precisely the kind of motive that undermines the credibility of the work produced. The problem? Let us consider the quote just mentioned in its original form: "When I wrote my treatise about our Systeme, I had an eye upon such Principles as might work with considering men for the beliefe of a Deity and nothing can rejoice me more than to find it useful for that purpose" (Davis, 1996, 78). Applying Pynes's criteria, Newton's Principia Mathematica should be rejected because of his religious motives. The same goes for Boyle, Faraday, and the work of hundreds of other scientists past and present. We conclude that Pynes's liberal use of ad hominem is far too liberal.

Our plea is that we leave these kinds of rhetorical tactics to the Rush Limbaughs of the world. We can engage in motive mongering all we like, but at the end of the day, none of that matters when it comes to logical evaluation. What does matter is what each party brings to the table in terms of arguments based on publicly available evidence. The arguments stand or fall on their own merits, regardless of motivation. If ID is bad science, then make the case. Let us not pretend that, having identified the nefarious motives of our opponent, we have thereby offered a counterargument. Pynes would not want his own work to be assessed in that manner. Let us extend that same intellectual grace to those with whom we disagree. ${ }^{1}$ 


\section{NOTE}

1. We wish to thank $\mathrm{Al}$ Lent for his help with this paper.

\section{REFERENCES}

Behe, Michael. 2001. "The Modern Intelligent Design Hypothesis." Philosophia Christi 3(1): 165-79.

Davis, Edward B. 1996. "Newton's Rejection of the 'Newtonian World View': The Role of Divine Will in Newton's Natural Philosophy." In Facets of Faith and Science: The Role of Beliefs in the Natural Science, Vol. 3, ed. Jitse M. van der Meer,[space]75-96. Lanham, MD: University Press of America.

Dembski, William. 2007. No Free Lunch: Why Specified Complexity Cannot Be Purchased Without Intelligence. Lanham, MD: Rowman \& Littlefield.

Koperski, Jeffrey. 2008. "Two Bad Ways to Attack Intelligent Design and Two Good Ones." Zygon: Journal of Religion and Science 43(2):433-49.

Pynes, Christopher A. 2012. "Ad Hominem Arguments and Intelligent Design: Reply to Koperski." Zygon: Journal of Religion and Science 47(2):289-97. 